\title{
Extracellular Polymer of Candida albicans: Isolation, Analysis and Role in Adhesion
}

\author{
By JANE McCOURTIE AND L. JULIA DOUGLAS* \\ Department of Microbiology, University of Glasgow, Garscube Estate, Bearsden, \\ Glasgow G61 1QH, UK
}

(Received 23 August 1984; revised 31 October 1984)

\begin{abstract}
Extracellular polymeric material (EP) was isolated from culture supernatants of Candida albicans grown on carbon sources ( $50 \mathrm{~mm}$-glucose, $500 \mathrm{mM}$-sucrose or $500 \mathrm{~mm}$-galactose) known to promote yeast adhesion to different extents. Galactose-grown yeasts, which are the most adherent, produced more EP than sucrose-grown organisms, particularly after incubation for $5 \mathrm{~d}$, while glucose-grown yeasts (the least adherent) gave the lowest yield. EP produced on all three carbon sources was of similar composition and contained carbohydrate (65 to $82 \%$; mannose with some glucose), protein $(7 \%)$, phosphorus $(0.5 \%)$ and glucosamine $(1.5 \%)$. Serological studies indicated that these EP preparations were immunologically identical but that galactose-grown yeasts had more antigenic determinants than sucrose-grown organisms while glucose-grown yeasts had the fewest determinants. Antigenic differences were apparent between EP preparations of some strains of C. albicans. Pretreatment of acrylic strips with EP to form a polymeric coating promoted yeast adhesion to the acrylic surface, but similar pretreatment of buccal epithelial cells with EP inhibited subsequent yeast adhesion. These results indicate that EP originates from the cell surface of $C$. albicans and that it contains the surface component(s), probably mannoprotein in nature, responsible for yeast adhesion.
\end{abstract}

\section{INTRODUCTION}

Oral thrush and denture stomatitis are two of the commonest forms of superficial candidosis (Odds, 1979). Adhesion of Candida albicans to buccal epithelial cells or to the acrylic denture can be regarded as the first stage in the pathogenesis of these diseases. Using $C$. albicans strains isolated from active infections, we have previously shown that adhesion to either surface in vitro is substantially increased after growth of the yeast in defined media containing high concentrations of certain sugars, notably galactose and sucrose, as the carbon source (McCourtie \& Douglas, 1981; Douglas et al., 1981; McCourtie \& Douglas, 1984). Organisms grown in medium containing $500 \mathrm{~mm}$-galactose, for example, are up to eleven times more adherent than control yeasts grown in medium with a relatively low concentration (50 mM) of glucose. Enhanced adhesion appears to result from the production of an additional fibrillar layer on the yeast cell surface, a change which also confers increased resistance to spheroplast formation with Zymolyase-5000 and increased virulence of the yeast for mice (McCourtie \& Douglas, 1984). Thus, organisms harvested from medium containing $500 \mathrm{~mm}$-galactose are more adherent, more resistant to spheroplast formation and more virulent than are $50 \mathrm{~mm}$-glucosegrown yeasts, in which the fibrillar component is largely absent.

A fibrillar-floccular layer on the surface of $C$. albicans growing in vivo has been demonstrated by electron microscopy of scrapings taken from the tongue and buccal mucosa of patients with oral candidosis (Montes \& Wiborn, 1968; Mohamed, 1975; Marrie \& Costerton, 1981). In such preparations the fibrils could be seen to mediate yeast attachment to epithelial cells. In vitro,

Abbreviation: EP, extracellular polymeric material. 
synthesis of the fibrillar layer in response to high concentrations of sugar takes place during the stationary phase of growth (Douglas \& McCourtie, 1981) and electron microscopy of stationaryphase organisms suggests that fibrils are released from the yeast surface relatively readily (McCourtie \& Douglas, 1981). The present paper describes the isolation and analysis of extracellular polymeric material (EP) from culture supernatants of $C$. albicans and provides evidence that this material originates from the yeast surface where it plays a role in adhesion.

\section{METHODS}

Organisms. Four strains of $C$. albicans were used in this study. Candida albicans MRL 3153 was from the Mycological Reference Laboratory at the London School of Hygiene and Tropical Medicine, London, UK. The remaining three strains were isolated in Glasgow and have recently been deposited with the National Collection of Yeast Cultures (NCYC), Food Research Institute, Norwich, UK. Candida albicans BP 3968 (NCYC 1466) was obtained from a cutaneous candidosis lesion; strains GDH 2346 (NCYC 1467) and GDH 2023 (NCYC 1468) were isolated at Glasgow Dental Hospital from patients with denture stomatitis. The organisms were maintained on slopes of Sabouraud dextrose agar (Difco) and subcultured monthly. Every two months the cultures were replaced by new ones freshly grown from freeze-dried stocks.

Growth conditions. The yeasts were grown in yeast nitrogen base medium (Difco) containing 50 mM-glucose, $500 \mathrm{~mm}$-sucrose or $500 \mathrm{~mm}$-galactose as described previously (McCourtie \& Douglas, 1981). The organisms grew at similar rates, and exclusively in the budding yeast phase, in all of these media. They were harvested after $24 \mathrm{~h}$ (stationary growth phase) and washed twice in $0.15 \mathrm{M}$-phosphate-buffered saline (PBS), pH 7.2.

Isolation of EP. EP was isolated from culture supernatants by precipitation with acetone. Batches of medium $\left(500 \mathrm{ml}\right.$ in 2 litre Erlenmeyer flasks) were inoculated with overnight yeast cultures $(50 \mathrm{ml})$ and incubated at $37^{\circ} \mathrm{C}$ for $24 \mathrm{~h}$ or $5 \mathrm{~d}$ in an orbital shaker operating at 150 r.p.m. Yeasts were removed by centrifugation and culture supernatant $(500 \mathrm{ml})$ was added to 1.5 vols cold $\left(4^{\circ} \mathrm{C}\right)$ acetone containing approximately $1 \mathrm{~g}$ sodium acetate to aid precipitation. After $2 \mathrm{~h}$ at $4{ }^{\circ} \mathrm{C}$, the resultant precipitate was collected by centrifugation at $17000 \mathrm{~g}$ for $30 \mathrm{~min}$. The pellet was redissolved in a small volume $(10$ to $15 \mathrm{ml})$ of distilled water and any insoluble material was removed by centrifugation. Water-soluble polymer was recovered by acetone precipitation $\left(3\right.$ vols; $2 \mathrm{~h}$ at $\left.4{ }^{\circ} \mathrm{C}\right)$, washed with ether and evaporated to dryness in vacuo. The dried material was weighed and the yield was calculated as a percentage of the combined dry weight of yeast cells and EP.

Crude EP preparations, dissolved in a minimum volume of distilled water, were dialysed at $4{ }^{\circ} \mathrm{C}$ for $24 \mathrm{~h}$ against two changes ( 9 litres each) of distilled water. EP in the retentate was precipitated with acetone, dried and weighed. All samples, dialysed and undialysed, were stored at $-20^{\circ} \mathrm{C}$. Qualitative or quantitative analyses, adherence assays and immunological studies were done only with dialysed material. Prior to analysis for carbohydrate, in some cases, EP preparations were treated with detergent. EP was dissolved in $0.1 \%$ Triton X-100 and the solution was stirred continuously at room temperature for $5 \mathrm{~h}$. Detergent-treated EP was recovered by precipitation with acetone ( 2 vols; $2 \mathrm{~h}$ at $4^{\circ} \mathrm{C}$ ), washed with ether and evaporated to dryness in vacuo.

Analysis of EP. Qualitative analysis of EP preparations was done by paper chromatography of acid hydrolysates; results were confirmed by gas-liquid chromatography (kindly performed by Dr John G. Beeley). EP $\left(2 \mathrm{mg}\right.$ ) was hydrolysed in $2 \mathrm{M}-\mathrm{HCl}(\mathrm{I} \mathrm{ml})$ at $105^{\circ} \mathrm{C}$ for $3 \mathrm{~h}$ in sealed ampoules. Hydrolysates were evaporated to dryness in vacuo, redissolved in a few drops of distilled water and subjected to descending chromatography on Whatman no. 1 paper in butan-1-ol/pyridine/water $(6: 4: 3$, by vol.; Jeanes $e$ t al., 1951). Hydrolysis products and standard sugars were visualized with alkaline silver nitrate (Trevelyan et al., 1950).

For quantitative analysis, protein was determined by the Lowry method and phosphorus by the method of Chen et al. (1956). Total carbohydrate was estimated according to the procedure of Dubois et al. (1956), using mannose as a standard. Glucose content was determined with a Boehringer GOD-Perid test combination after hydrolysis of samples in $0.5 \mathrm{M}-\mathrm{HCl}$ at $100^{\circ} \mathrm{C}$ for $5 \mathrm{~h}$. Hexosamine was estimated by the method of Blumerkrantz \& AsboeHansen (1976) using glucosamine as a standard; before analysis, samples were hydrolysed in $1 \mathrm{M}-\mathrm{HCl}$ at $105^{\circ} \mathrm{C}$ for $6 \mathrm{~h}$.

Adhesion assays. Yeast adhesion to transparent acrylic strips or to exfoliated human buccal epithelial cells was determined by light microscopy as described previously (McCourtie \& Douglas, 1984).

Preparation of antisera. Dialysed EP $(20 \mathrm{mg})$ was dissolved in saline $(0.5 \mathrm{ml})$ and mixed thoroughly with $0.5 \mathrm{ml}$ Bayol F (Esso; kindly provided by Dr D. E. S. Stewart-Tull) containing $250 \mu \mathrm{g}$ freeze-dried Mycobacterium tuberculosis and $0.2 \mathrm{ml}$ Arlacel A (Honeywell-Atlas, Carshalton, Surrey, UK). Groups of five HaM/ICR mice, aged 6 weeks, were injected intraperitoneally with $0.1 \mathrm{ml}$ of this mixture of EP in complete Freund's adjuvant. Control mice were inoculated with saline. After $14 \mathrm{~d}$, slide agglutination tests for antibody production proved positive and the mice were bled by cardiac puncture. Sera were collected by centrifugation at $1200 \mathrm{~g}$ and samples from each batch of five mice were pooled.

Antiserum was also prepared in guinea pigs (Dunkin-Hartley) by intramuscular injection of $0.2 \mathrm{ml} \mathrm{EP}$ in 
adjuvant into the inner aspect of the hind limbs. Production of antibodies was monitored after $19 \mathrm{~d}$ and the guinea pigs were bled by cardiac puncture after $21 \mathrm{~d}$.

Agglutinin absorption. Portions $(1.5 \mathrm{ml})$ of $24 \mathrm{~h}$ yeast cultures were centrifuged in a Beckman microfuge B at $8740 \mathrm{~g}$ for $1 \mathrm{~min}$. The organisms were washed in saline and resuspended in $0.5 \mathrm{ml}$ antiserum. These mixtures were incubated at $37^{\circ} \mathrm{C}$ for $30 \mathrm{~min}$ and then centrifuged to remove the yeast cells. The procedure was repeated (five times in all), using the same sera, until no residual antibodies to the absorbing cells could be detected in slide agglutination tests.

Agglutination assays. The tests were set up in microtitre trays (Sterilin) using doubling dilutions $(0.05 \mathrm{ml})$ of antisera in saline to which were added equal volumes $(0.05 \mathrm{ml})$ of $C$. albicans suspended in saline $\left(10^{7}\right.$ yeast cells $\left.\mathrm{ml}^{-1}\right)$. Control sera were treated in the same way. An additional control consisted of yeast cell suspension (0.05 $\left.\mathrm{ml}\right)$ and saline $(0.05 \mathrm{ml})$. Complete mixing was achieved by sideways agitation and the trays were incubated at $37^{\circ} \mathrm{C}$ for $1 \mathrm{~h}$. The endpoint of titration was taken as the highest dilution of antiserum which gave visible agglutination of the yeast suspensions. The trays were incubated at $4{ }^{\circ} \mathrm{C}$ overnight to check for any increase in titres. All agglutination tests were done in duplicate and the mean titre calculated. Normal sera gave zero titres.

\section{RESULTS}

\section{Yields of EP}

EP was isolated from culture supernatants of $C$. albicans GDH 2346 by precipitation with acetone. More EP was recovered from supernatants of cultures grown in $500 \mathrm{mM}$-sucrose or galactose than from those of cultures grown in $50 \mathrm{~mm}$-glucose (Table 1). This was particularly evident after an incubation period of $5 \mathrm{~d}$ when there was a significant increase in the amount of material isolated, especially from galactose-grown cultures; the yield of EP for galactose-grown yeasts was $17 \cdot 1 \%$, compared with $10.5 \%$ for sucrose-grown yeasts and $4.4 \%$ for glucose-grown organisms. Similar results were obtained with two other strains of C. albicans; strain BP 3968 gave EP yields of $20.7 \%, 15.2 \%$ and $8.6 \%$ from $5 \mathrm{~d}$ cultures of galactose-, sucrose- and glucosegrown yeasts respectively, while the corresponding figures for strain MRL 3153 were $19.3 \%$, $13.0 \%$ and $4.3 \%$.

With all three strains, EP prepared from culture supernatants of glucose- or sucrose-grown yeasts was crystalline and grey. Material obtained from culture supernatants of $500 \mathrm{mM}-$ galactose-grown organisms, however, was grey-green. The green colour was particularly noticeable with EP from strain GDH 2346 and was presumably due to the presence of a green pigment known to be produced by $C$. albicans under certain conditions (Ashford, 1917; Jones \& Peck, 1940).

\section{Analysis of EP}

Paper chromatography of acid-hydrolysed EP from C. albicans GDH 2346 revealed mannose, glucose and glucosamine as the only identifiable sugars. An unidentified component $\left(R_{\mathrm{GlcN}}=0.78\right)$ was also visualized with alkaline silver nitrate. These findings were confirmed by gas-liquid chromatography, which also indicated that mannose was the major sugar present.

\section{Table 1. Yield of EP obtained from culture supernatants of C. albicans GDH 2346}

C. albicans GDH 2346 was grown for $1 \mathrm{~d}(24 \mathrm{~h})$ or $5 \mathrm{~d}$ in yeast nitrogen base medium containing glucose $(50 \mathrm{mM})$, sucrose $(500 \mathrm{mM})$ or galactose $(500 \mathrm{mM})$ as the carbon source. EP was isolated from culture supernatants by precipitation with acetone as described in Methods. Results represent means \pm SEM for 3-7 independent experiments. Yield is expressed as a percentage of the combined dry weight of yeast cells and EP. Probability values $(P)$ compare yields with those from corresponding cultures grown in medium containing $50 \mathrm{~mm}$-glucose.

\begin{tabular}{|c|c|c|c|c|c|}
\hline $\begin{array}{l}\text { Carbon } \\
\text { source }\end{array}$ & $\begin{array}{l}\text { Incubation } \\
\text { period (d) }\end{array}$ & $\begin{array}{l}\text { Dry wt of } \\
\text { yeasts }(\mathrm{g})\end{array}$ & $\begin{array}{l}\text { Dry wt of } \\
\text { EP (mg) }\end{array}$ & $\begin{array}{l}\text { Percentage } \\
\text { yield of EP }\end{array}$ & $P$ \\
\hline $\begin{array}{l}\text { Glucose } \\
\text { Sucrose } \\
\text { Galactose }\end{array}$ & $\begin{array}{l}1 \\
1 \\
1\end{array}$ & $\begin{array}{l}1.67 \pm 0.19 \\
2.69 \pm 0.59 \\
2.35 \pm 0.44\end{array}$ & $\begin{array}{r}75 \pm 12 \\
137 \pm 31 \\
137 \pm 20\end{array}$ & $\begin{array}{l}4 \cdot 3 \pm 0.5 \\
4 \cdot 8 \pm 0.2 \\
5.7 \pm 0.3\end{array}$ & $\begin{array}{c}\text { NS } \\
<0.05\end{array}$ \\
\hline $\begin{array}{l}\text { Glucose } \\
\text { Sucrose } \\
\text { Galactose }\end{array}$ & $\begin{array}{l}5 \\
5 \\
5\end{array}$ & $\begin{array}{l}1.94 \pm 0.19 \\
1.87 \pm 0.07 \\
2.72 \pm 0.46\end{array}$ & $\begin{array}{c}92 \pm 20 \\
221 \pm 41 \\
576 \pm 115\end{array}$ & $\begin{array}{r}4.4 \pm 0.8 \\
10.5 \pm 1.8 \\
17.1 \pm 1.5\end{array}$ & $\begin{array}{l}<0.025 \\
<0.001\end{array}$ \\
\hline
\end{tabular}




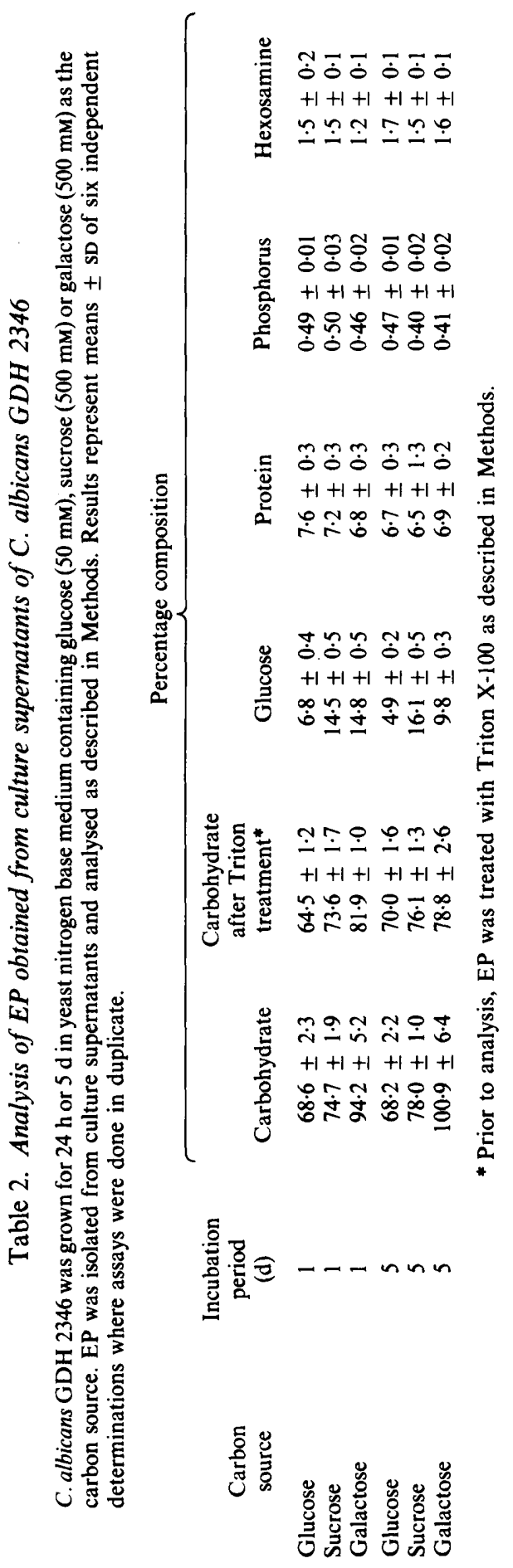


Table 3. Agglutination titres of serum raised against EP obtained from culture supernatants of C. albicans GDH 2346

C. albicans GDH 2346 grown in yeast nitrogen base medium containing $50 \mathrm{~mm}$-glucose, $500 \mathrm{~mm}$-sucrose or $500 \mathrm{~mm}$-galactose was assayed with sera raised in (A) guinea pigs or (B) mice. Results shown are mean values for duplicate titres.

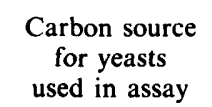

A. Glucose

Sucrose

Galactose

B. Glucose

Sucrose

Galactose

$\begin{array}{r}\text { Reciprocal t } \\ \text { prod }\end{array}$
Glucose (50 mM)
32
128
512
12
192
128

Reciprocal titre of antiserum raised against EP produced by yeasts grown on:

$\begin{array}{cr}\text { Sucrose }(500 \mathrm{mM}) & \text { Galactose }(500 \\ 24 & 32 \\ 128 & 192 \\ 512 & 768 \\ 8 & 8 \\ 768 & 3072 \\ 4096 & 8192\end{array}$

The results of quantitative analyses are shown in Table 2. Initially, values obtained for the carbohydrate content of EP produced by galactose-grown yeasts were very high and, on occasion, in excess of $100 \%$. This appeared to be due to interference in the assay by the green pigment present in these preparations, since treatment with $0.1 \%$ Triton $\mathrm{X}-100$ for $5 \mathrm{~h}$ at room temperature decreased the carbohydrate content to values more comparable with those obtained for the other EP preparations analysed. Prolonged extraction with Triton X-100 had no further effect. The carbohydrate content of EP produced by glucose- or sucrose-grown yeasts was completely unaffected by detergent treatment.

The overall composition of different EP preparations was quite similar, irrespective of the carbon source or incubation period (Table 2). They comprised 65 to $82 \%$ carbohydrate (mainly mannose), with smaller amounts of protein $(7 \%)$, phosphorus $(0.5 \%)$ and glucosamine $(1.5 \%)$. EP produced by glucose-grown yeasts had less carbohydrate and a correspondingly lower glucose content than the other EP preparations.

\section{Immunological studies}

Possible structural differences between EP preparations were investigated serologically. Antiserum was raised in both mice and guinea pigs against EP produced by $C$. albicans GDH 2346 in medium containing $50 \mathrm{~mm}$-glucose, $500 \mathrm{~mm}$-sucrose or $500 \mathrm{~mm}$-galactose. The sera were then tested in agglutination experiments with suspensions of yeast cells of the same strain grown on each of the three carbon sources. Increasing titres were obtained in going from glucose-grown yeasts to sucrose-grown yeasts and finally to galactose-grown organisms (Table 3). This was true of all three types of serum raised in either animal species, although mouse sera gave higher titres. These results suggest immunological identity between the different EP preparations. They also indicate that there are more antigenic determinants on the surface of galactose-grown yeasts than on sucrose-grown yeasts and that the latter in turn possess more determinants than organisms grown on $50 \mathrm{~mm}$-glucose.

Immunological identity of the EP preparations was confirmed by means of agglutininabsorption experiments. Antiserum raised against EP from galactose-grown yeasts was absorbed with organisms grown in medium containing $50 \mathrm{~mm}$-glucose, $500 \mathrm{~mm}$-sucrose or $500 \mathrm{~mm}$-galactose. Yeasts were removed by centrifugation and the procedure was repeated with the supernatant until no reaction with absorbing cells could be detected in slide agglutination tests. An analogous protocol was employed with the two other sera, and the nine resulting absorbed antisera were then used in agglutination assays with C. albicans GDH 2346 grown in medium containing $50 \mathrm{~mm}$-glucose, $500 \mathrm{~mm}$-sucrose or $500 \mathrm{~mm}$-galactose. No appreciable agglutination of these organisms by any of the absorbed sera could be detected.

Two further strains of $C$. albicans were used in cross-agglutination tests (Table 4). Incubation of suspensions of C. albicans MRL 3153 with antisera raised against EP from strain GDH 2346 
Table 4. Cross-agglutination titres of serum raised against EP obtained from culture supernatants of C. albicans $G D H 2346$

Sera raised in guinea pigs were assayed with (A) C. albicans MRL 3153 and (B) C. albicans GDH 2023 grown in medium containing $50 \mathrm{~mm}$-glucose, $500 \mathrm{~mm}$-sucrose or $500 \mathrm{~mm}$-galactose. Results shown are mean values for duplicate titres.

\author{
Carbon source \\ for yeasts \\ used in assay
}

\begin{tabular}{|c|c|c|}
\hline Glucose $(50 \mathrm{~mm})$ & Sucrose $(500 \mathrm{~mm})$ & Galactose $(500 \mathrm{~mm})$ \\
\hline $\begin{array}{r}24 \\
128 \\
64\end{array}$ & $\begin{array}{r}96 \\
256 \\
192\end{array}$ & $\begin{array}{l}128 \\
512 \\
384\end{array}$ \\
\hline $\begin{array}{r}12 \\
8 \\
8\end{array}$ & $\begin{array}{l}8 \\
8 \\
6\end{array}$ & $\begin{array}{r}12 \\
8 \\
12\end{array}$ \\
\hline
\end{tabular}

\title{
Table 5. Effect of pretreatment of acrylic with EP on the subsequent adhesion of C. albicans $G D H 2346$
}

\begin{abstract}
Prior to adhesion assays, acrylic strips were incubated for $4 \mathrm{~h}$ at room temperature in solutions $\left(5 \mathrm{mg} \mathrm{ml}^{-1}\right.$ ) of EP produced by $C$. albicans $\mathrm{GDH} 2346$ in medium containing $50 \mathrm{~mm}$-glucose, $500 \mathrm{~mm}$ sucrose or $500 \mathrm{~mm}$-galactose. Control strips were preincubated for $4 \mathrm{~h}$ in PBS. All strips were then withdrawn, shaken to remove excess liquid and used in adhesion assays with $C$. albicans GDH 2346 grown in medium containing $50 \mathrm{~mm}$-glucose or $500 \mathrm{~mm}$-sucrose.
\end{abstract}

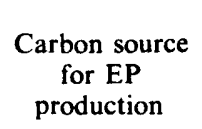

Glucose

Sucrose

Galactose

Sucrose

Galactose

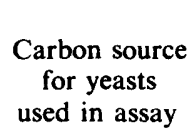

Glucose

Glucose

Glucose

Sucrose

Sucrose
Mean no. ( \pm SEM) of adherent yeasts

per $\mathrm{mm}^{2}$ of acrylic treated with:

$\begin{array}{cc}\text { PBS } & \text { EP } \\ 104 \pm 3 & 108 \pm 3 \\ 104 \pm 6 & 198 \pm 16 \\ 106 \pm 8 & 242 \pm 13 \\ 320 \pm 5 & 339 \pm 4 \\ 354 \pm 6 & 450 \pm 8\end{array}$

$\begin{array}{cc}\begin{array}{c}\text { Relative } \\ \text { adherence* }\end{array} & P \dagger \\ 1.0 & \text { NS } \\ 1.9 & <0.001 \\ 2.3 & <0.001 \\ 1 \cdot 1 & <0.025 \\ 1.3 & <0.001\end{array}$

* Adherence to EP-coated acrylic compared with that to PBS-treated acrylic.

† Probability values comparing adherence to EP-coated acrylic with that to PBS-treated acrylic. NS, Not significant.

produced a pattern of titres similar to that obtained with the homologous yeast cells, indicating a similarity between the EP produced by these two strains. Incubation of the same sera with suspensions of $C$. albicans GDH 2023, on the other hand, gave much lower titres, suggesting marked differences in EP antigenicity between these strains.

\section{Effect of EP on yeast adhesion in vitro}

Increased yields of EP from galactose-grown or sucrose-grown organisms after incubation for $5 \mathrm{~d}$ (Table 1) correlated with enhanced ability of the yeasts to adhere to acrylic in vitro. For example, the adhesion of $C$. albicans GDH 2346 incubated in medium containing $500 \mathrm{~mm}$ sucrose for $5 \mathrm{~d}$ was double that of yeasts incubated similarly for only $24 \mathrm{~h}$ (data not shown). Moreover, pretreatment of acrylic strips with EP to form a polymeric coating promoted adhesion in most cases (Table 5). EP obtained from glucose-grown yeasts had no effect on the adhesion of these organisms to acrylic but EP isolated from culture supernatants of sucrosegrown cells increased the adherence of sucrose-grown and, to a greater extent, glucose-grown organisms. The biggest increase was observed when glucose-grown yeasts were incubated with acrylic which had been pretreated with EP obtained from galactose-grown organisms: attachment was more than doubled. Thus, precoating acrylic with EP was most effective at promoting adhesion when EP derived from the most adherent yeast type was used in assays with organisms of the least adherent type. 
Table 6. Effect of pretreatment of buccal epithelial cells with EP on the subsequent adhesion of C. albicans GDH 2346 and GDH 2023

Prior to adhesion assays, buccal epithelial cells were incubated for $30 \mathrm{~min}$ at $37^{\circ} \mathrm{C}$ in PBS or in a solution ( $5 \mathrm{mg} \mathrm{ml}^{-1}$ ) of EP produced by $C$. albicans GDH 2346 or GDH 2023 in medium containing $500 \mathrm{~mm}$-galactose. After this pretreatment, buccal cells were recovered by centrifugation, resuspended in PBS and used in adhesion assays with the indicated strain of $C$. albicans grown in medium containing $50 \mathrm{~mm}$-glucose, $500 \mathrm{~mm}$-sucrose or $500 \mathrm{~mm}$-galactose.

\begin{tabular}{|c|c|c|c|c|c|}
\hline \multirow[b]{2}{*}{ Strain } & \multirow{2}{*}{$\begin{array}{l}\text { Carbon source } \\
\text { in growth } \\
\text { medium }\end{array}$} & \multicolumn{2}{|c|}{$\begin{array}{l}\text { Mean no. }( \pm \text { SEM }) \text { of adherent yeasts per } \\
100 \text { epithelial cells pretreated with: }\end{array}$} & \multirow{2}{*}{$\begin{array}{c}\text { Relative } \\
\text { adherence* }\end{array}$} & \multirow[b]{2}{*}{$P \dagger$} \\
\hline & & PBS & EP & & \\
\hline \multicolumn{6}{|c|}{ (a) EP from strain GDH 2346} \\
\hline GDH 2346 & Glucose & $114 \pm 5$ & $104 \pm 6$ & 0.9 & NS \\
\hline GDH 2346 & Sucrose & $387 \pm 17$ & $292 \pm 18$ & 0.7 & $<0.01$ \\
\hline GDH 2346 & Galactose & $847 \pm 47$ & $451 \pm 27$ & $0 \cdot 5$ & $<0.001$ \\
\hline \multicolumn{6}{|c|}{ (b) EP from strain GDH 2023} \\
\hline GDH 2023 & Galactose & $871 \pm 34$ & $419 \pm 38$ & $0 \cdot 5$ & $<0.001$ \\
\hline GDH 2346 & Galactose & $692 \pm 23$ & $695 \pm 33$ & $1 \cdot 0$ & NS \\
\hline
\end{tabular}

A different result was obtained when buccal epithelial cells were preincubated with EP obtained from galactose-grown $C$. albicans GDH 2346 (Table $6 a$ ). Such treatment decreased the adhesion of yeast cells grown in medium containing $500 \mathrm{~mm}$-sucrose or galactose by $30 \%$ and $50 \%$ respectively. The adhesion of $50 \mathrm{mM}$-glucose-grown yeasts, however, was unaffected. After incubation with EP for $30 \mathrm{~min}$ at $37^{\circ} \mathrm{C}$, epithelial cells tended to aggregate. To prevent this affecting adhesion assays, the epithelial cells were recovered by centrifugation ( $1200 \mathrm{~g}$ for $5 \mathrm{~min}$ ) and resuspended in PBS; control cells incubated with PBS were treated similarly.

The adhesion of C. albicans GDH 2346 and GDH 2023 to buccal cells pretreated with EP obtained from galactose-grown $C$. albicans GDH 2023 was also investigated (Table $6 b$ ). Adhesion of galactose-grown yeasts of the homologous strain was halved while that of galactosegrown $C$. albicans GDH 2346 was unaffected. These results are consistent with those of the cross-agglutination experiments described above, which indicated differences in the nature of the EP produced by these two strains.

\section{DISCUSSION}

Previous work has shown that growth of $C$. albicans in medium containing high concentrations of certain sugars can promote the synthesis of a fibrillar layer on the yeast surface (McCourtie \& Douglas, 1981). The fibrils, which have also been described as fungal fimbriae (Gardiner et al., 1982), enhance yeast attachment to epithelial and acrylic surfaces in vitro (McCourtie \& Douglas, 1984). The results reported in this paper indicate that fibrils are released into the surrounding environment upon prolonged incubation of the yeast at $37^{\circ} \mathrm{C}$ and that polymeric material isolated from culture supernatants contains the fibrillar adhesin.

Yeasts grown in medium with a high concentration of galactose or sucrose are more adherent than those grown in a relatively low concentration of glucose (McCourtie \& Douglas, 1984). It was not unexpected, therefore, that more EP could be recovered from culture supernatants of galactose- or sucrose-grown yeasts than from those of glucose-grown organisms. The strains of C. albicans used in this study grew at similar rates on all three carbon sources irrespective of initial concentration ( $50 \mathrm{~mm}$ or $500 \mathrm{mM}$ ). Thus, growth limitation was not due to depletion of the carbon source but must, rather, have resulted from exhaustion of some other constituent of the growth medium. Production of the fibrillar layer by $C$. albicans may therefore be analogous to exopolysaccharide synthesis by bacteria where maximum yields are often obtained in medium 
containing excess carbohydrate in which growth is limited by the availability of nitrogen, phosphorus or sulphur (Sutherland, 1977).

Quantitative analysis of EP indicated that it has a high mannose content and is probably largely mannoprotein in nature. This conclusion is consistent with our earlier studies with the antibiotic tunicamycin which, in yeasts, is a specific inhibitor of mannoprotein synthesis. Addition of tunicamycin to $500 \mathrm{~mm}$-galactose-grown cultures at the onset of the stationary phase of growth decreased yeast adhesion and increased yeast sensitivity to spheroplast formation, presumably by inhibiting synthesis of the fibrillar surface layer (Douglas \& McCourtie, 1983). Removal of surface mannoprotein from C. albicans by warm water washes has been reported by Sikl et al. (1964). The same authors (Masler et al., 1966) have also described the isolation from yeast culture supernatants of polysaccharide-protein complexes similar in composition to EP prepared in this study. The extracellular material was obtained from cultures grown in medium containing $2 \%(\mathrm{w} / \mathrm{v})$ glucose for one week; it was immunologically active and could be separated electrophoretically into two or three distinct components, depending on the strain. Preliminary fractionation of our EP preparations also indicates the presence of more than one component (unpublished results).

Quantitative analysis failed to reveal significant differences in the chemical composition of EP produced by strain GDH 2346 on different carbon sources. Moreover, serological studies indicated that the EP preparations from this strain were immunologically identical, but that $500 \mathrm{~mm}$-galactose-grown yeasts had more antigenic determinants, and thus presumably a more extensive fibrillar layer than $500 \mathrm{~mm}$-sucrose-grown organisms, while $50 \mathrm{~mm}$-glucose-grown yeasts had the fewest determinants/fibrils. The physiological basis of this phenotypic variation in yeast surface composition remains to be established. Cross-agglutination tests indicated a similarity of surface structure in C. albicans GDH 2346 and MRL 3153. However, antigenic differences were apparent between strains GDH 2346 and GDH 2023 and preliminary analyses also indicate differences in the chemical composition of EP preparations from these two strains (unpublished data). C. albicans MRL 3153 is known to correspond to serotype A of Hasenclever \& Mitchell (1961). Although the serotypes of the Glasgow isolates used in this study have not been determined, our present results suggest that strains GDH 2346 and GDH 2023 may represent serotypes $A$ and $B$, respectively.

The adhesion of micro-organisms to mucosal surfaces is believed to involve specific interactions between microbial adhesins and complementary host-cell receptors. Adhesion to epithelial cells in vitro can be blocked by adding an excess of isolated adhesin or receptor (or their analogues) to assay mixtures where either substance will function as a competitive inhibitor (Ofek \& Beachey, 1980). In the present investigation, inhibition was observed when epithelial cells were pretreated with EP, indicating that this extracellular material contained the yeast adhesin. These results, together with our analytical data (Table 2), also provide further evidence for the mannoprotein nature of the adhesin (Sandin et al., 1982; Douglas \& McCourtie, 1983; Lee \& King, 1983). However, the finding that EP from strain GDH 2023 does not inhibit adhesion of strain GDH 2346 (Table 6) suggests that the adhesins of these two strains may be different.

In aquatic environments, adsorption of macromolecules on solid surfaces results in a modified surface charge which may promote or inhibit microbial attachment (Wardell et al., 1983). For example, Corpe (1970) reported that marine bacteria adhered in greater numbers to glass slides precoated with bacterial exopolysaccharide than to uncoated slides. Adhesion of $C$. albicans to acrylic was similarly enhanced when acrylic strips were pretreated with EP (Table 5). The effect was particularly marked with EP preparations from galactose-grown yeasts which presumably contained the highest proportion of yeast adhesin. If non-specific polymeric bridging of this type also occurred in assays with EP-treated buccal cells, it would tend to counteract the specific inhibition due to blocked epithelial receptors. This may explain the apparent absence of inhibition with glucose-grown yeasts in such assays.

J. McC. was the recipient of a Medical Research Council studentship. We are indebted to Drs D. E. S. StewartTull and J. G. Beeley for helpful discussions. 


\section{REFERENCES}

ASHFORD, B. K. (1917). The etiology of sprue. American Journal of Medical Sciences 154, 157-176.

Blumerkrantz, N. \& Asboe-Hansen, E. (1976). An assay for total hexosamine and a differential assay for glucosamine and galactosamine. Clinical Biochemistry 9, 269-274.

Chen, P. S., Toribara, T. Y. \& Warner, H. (1956). Microdetermination of phosphorus. Analytical Chemistry 28, 1756-1758.

CORPE, W. A. (1970). An acid polysaccharide produced by a primary film-forming marine bacterium. Developments in Industrial Microbiology 11, 402-412.

Douglas, L. J. \& McCourTiE, J. (1981). Adherence of Candida albicans to denture acrylic as affected by changes in cell-surface composition. In Current Developments in Yeast Research, pp. 375-380. Edited by G. G. Stewart \& I. Russell. Toronto: Pergamon Press.

Douglas, L. J. \& McCourtie, J. (1983). Effect of tunicamycin treatment on the adherence of Candida albicans to human buccal epithelial cells. FEMS Microbiology Letters 16, 199-202.

Douglas, L. J., Houston, J. G. \& McCourtie, J. (1981). Adherence of Candida albicans to human buccal epithelial cells after growth on different carbon sources. FEMS Microbiology Letters 12, 241243.

Dubois, M., Gilles, K. A., Hamilton, J. K., Rebers, P. A. \& SMITH, F. (1956). Colorimetric method for determination of sugars and related substances. Analytical Chemistry 28, 350-356.

GARdiner, R., Podgorski, C. \& DAY, A. W. (1982). Serological studies on the fimbriae of yeasts and yeastlike species. Botanical Gazette 143, 534-541.

Hasenclever, H. F. \& Mitchell, W. O. (1961). Antigenic studies of Candida. I. Observation of two antigenic groups in Candida albicans. Journal of Bacteriology 82, 570-573.

Jeanes, A., Wise, C. S. \& Dimler, R. J. (1951). Improved techniques in paper chromatography of carbohydrates. Analytical Chemistry 23, 415-420.

Jones, C. P. \& PECK, R. L. (1940). A green pigment from Candida stellatoidea and Candida albicans. Journal of Bacteriology 39, 605-608.

LEE, J. C. \& KING, R. D. (1983). Characterization of Candida albicans adherence to human vaginal epithelial cells in vitro. Infection and Immunity 41, 10241030.
MARrie, T. J. \& Costerton, J. W. (1981). The ultrastructure of Candida albicans infections. Canadian Journal of Microbiology 27, 1156-1164.

MASLER, L., ŠIKL, D., BAUER, S. \& ŚANDULA, J. (1966). Extracellular polysaccharide-protein complexes produced by selected strains of Candida albicans (Robin) Berkhout. Folia microbiologica 11, 373-378.

MCCourtie, J. \& Douglas, L. J. (1981). Relationship between cell surface composition of Candida albicans and adherence to acrylic after growth on different carbon sources. Infection and Immunity 32, 12341241.

McCourtie, J. \& Douglas, L. J. (1984). Relationship between cell surface composition, adherence and virulence of Candida albicans. Infection and Immunity 45, 6-12.

MOHAMED, A-M. H. (1975). Ultrastructural aspects of chronic oral candidosis. Journal of Oral Pathology 4, 180-194.

MoNTES, L. F. \& WILBORN, W. H. (1968). Ultrastructural features of host-parasite relationship in oral candidosis. Journal of Bacteriology 96, 1349-1356.

ODDs, F. C. (1979). Candida and Candidosis. Leicester: Leicester University Press.

OFEK, I. \& BEACHEY, E. H. (1980). General concepts and principles of bacterial adherence in animals and man. In Bacterial Adherence, Receptors and Recognition, Series B, vol. 6, pp. 1-29. Edited by E. H. Beachey. London: Chapman \& Hall.

Sandin, R. L., Rogers, A. L., Patterson, R. J. \& BENEKE, E. S. (1982). Evidence for mannosemediated adherence of Candida albicans to human buccal cells in vitro. Infection and Immunity 35, 79-85.

ŠIKL, D., Masler, L. \& BaUER, S. (1964). Mannan from the extracellular surface of Candida albicans Berkhout. Experientia 20, 456.

SuTHERLAND, I. W. (1977). Bacterial exopolysaccharides - their nature and production. In Surface Carbohydrates of the Prokaryotic Cell, pp. 27-96. Edited by I. W. Sutherland. London: Academic Press.

Trevelyan, W. E., Proctor, D. P. \& Harrison, J. S. (1950). Detection of sugars on paper chromatograms. Nature, London 166, 444-445.

Wardell, J. N., Brown, C. M. \& Flannigan, B. (1983). Microbes and surfaces. Symposia of the Society for General Microbiology 34, 351-378. 